\section{Collective trust as a social indicator of the instructionalcapacity: A qualitative research}

\section{Öğretim kapasitesinin sosyal bir göstergesi olarak kolektif güven: Nitel bir araştırma ${ }^{1}$}

\author{
Nezahat Güçlü² \\ Nagihan Tepe ${ }^{3}$ \\ Şayma Duman ${ }^{4}$
}

\begin{abstract}
Instructional capacity at school has two interconnected basic characteristics. These are: resources which enable increase of teaching efficiency at schools and social processes which would enable occupational learning through forming information (Curt, 2012). Collective trust which is in the social step of instructional capacity is the characteristics of a stable group which has rooted perceptions and effected by the reliability of another group or individual (Forsyth, Adams, and Hoy, 2011). It is based on openness, honesty, cooperativeness and competency (Hoy and Tschannen-Moran, 1999). Collective trust is a social process which increases instructional capacity at school. Schools with high learning capacity aim to learn together. Leadership for everyone, learning for everyone and increasing success for everyone are the basic aims. More permanent and joyful learning is enabled by forming cooperative learning environment at these schools. All the individuals share vision and knows what to do to reach the aim and how to contribute. Communication at school reflects the quality of school. Student makes contribution to the system with his success in the process (Lambert, 2005). The aim of this study in which learning capacity and collective trust terms are discussed
\end{abstract}

\section{Özet}

Okullarda öğretim kapasitesinin birbirine bağlı iki temel özelliği vardır. Bunlar: okulda öğretim etkinliğini artırmayı sağlayan kaynaklar ve bilgi oluşturma ile mesleki öğrenmeyi sağlayacak olan sosyal süreçlerdir (Curt, 2012). Öğretim kapasitesinin sosyal basamağında yer alan kolektif güven; köklü algıları olan ve başka bir grup ya da bireyin güvenilirliğinden etkilenen durağan bir grup özelliğidir (Forsyth, Adams, and Hoy, 2011). Açılklik, dürüstlük, yardımseverlik, güvenirlik ve yetkinlik temeline dayanmaktadir (Hoy and Tschannen-Moran, 1999). Kolektif güven okullarda öğrenme kapasitesini artıran bir sosyal süreçtir. Öğrenme kapasitesi yüksek olan okullar birlikte öğrenmeyi amaçlar. Herkes için liderlik, herkes için öğrenme ve herkes için başarıyı yükseltmek temel hedeftir. Bu okullarda birlikte öğrenme ortamları oluşturarak daha kalıcı ve neşeli öğrenmeler oluşmaktadır. Müdür okullardaki liderlerden sadece biridir ve dinleme, işbirliği, uyum konusunda rol model olur. Tüm bireyler vizyonu paylaşır, amaçlara ulaşmak için ne yapmak gerektiğini ve nasıl katk1 sağlayacağını bilir. Okuldaki iletişim okulun kalitesini yansitur. Öğrenci süreçteki başarısı ile sisteme katkıda bulunur (Lambert, 2005).

\footnotetext{
${ }^{1}$ Bu çalışma 8.Ulusal Eğitim Yönetimi Kongresinde sözlü bildiri olarak sunulduktan sonra genişletilerek hazırlanmıştır. 2 Prof. Dr., Gazi University, Faculty of Gazi Education, Department of Educational Sciences, nguclu@gazi.edu.tr

3 Research Assistant, Ondokuz Mayıs University, Faculty of Education, Department of Educational Sciences, tepenagihan@gmail.com

4Ph.D. student,saymaduman@gmail.com
} 
Güçlü, N., Tepe, N., \&Duman, Ş. (2017). Öğretim kapasitesinin sosyal bir göstergesi olarak kolektif güven: Nitel bir araşturma. Journal of Human Sciences, 14(2), 1284-1297. doi:10.14687/jhs.v14i2.4492

is to determine the views of school principals about collective trust. Moreover, within this aim it was determined as sub-aims to analyze factors such as reliability, openness, honesty, helpfulness and competency in the process of school management. The study was carried out within the scope of "phenomenology" pattern which is one of the qualitative research patterns. The study group is composed of 10 school principals who were chosen with simple random sampling method. Data collected were analyzed with content analysis. Suggestions are presented in the light of findings and results.

Keywords: Trust; collective trust; instructional capacity; principal.

(Extended English abstract isat the end of this document)
Öğrenme kapasitesi ve kolektif güven kavramlarının tartışıldığ bu çalışmada amaç, okul yöneticilerinin kolektif güvenlerine ilişkin görüşlerini belirlemektir. Araştırma, nitel araştırma desenlerinden biri olan "olgu bilim" deseni kapsamında yürütülmüştür. Veri toplamak amaciyla kolektif güven kavramına ilişkin "okul yönetiminde açılklk, dürüstlük, yardımseverlik, sorumluluk ve yetkinlik" gibi faktörlerin incelendiği 10 açık uçlu sorudan oluşan yarı yapılandırılmış görüşme formu hazırlanmıştır. Bu görüşme formundaki sorular on okul yöneticisine yöneltilmiş, veriler içerik analizi tekniği kullanılarak analiz edilerek yorumlanmıştır. Bulgular ve sonuçlar ışığında öneriler sunulmuştur.

Anahtar Kelimeler: Güven; kolektif güven; öğretim kapasitesi; okul müdürü.

\section{Giriş}

İnsanlık tarihinde en köklü ve fazla sayıda dönüşümlerin yaşandığı zaman dilimi 20. yüzyıl olarak ifade edilebilir (Drucker, 2011; s. 191). Karip ve Köksal (1996; s. 245), 20. yüzy1lın ortalarında başlayarak, özellikle son çeyreğinde artan bu dönüşümlerin, ekonomik, sosyal, siyasal ve kültürel alanlarda olduğu gibi eğitim alanında da dönüşümü zorunlu kıldığını, bu amaçla eğitim sistemlerini geliştirmek amacıyla, gelişmiş ve gelişmekte olan ülkelerin çoğunun, son yıllarda birçok yenilikler yaptıklarını belirtmişlerdir. Bu yeniliklerin; eğitim sisteminde reformları, çağdaş kurumlar oluşturma çabalarını, teknolojik öğretim araç ve gereçlerin kullanılmasını, öğretmenlerin mesleki bilgi ve beceri düzeylerinin geliştirilmesini ve okul yönetiminde yenilikler yoluyla öğretme-öğrenme sürecini geliştirmeye yönelik değişik politika ve uygulamaları kapsadığını ifade etmişlerdir.

Eğitim ve değişim arasında çift yönlü bir etkileşim söz konusu olduğundan eğitim, bir yandan toplumdaki değişmelerden etkilenip, bu değişmelere göre kendini yeniden düzenleme gereği duyarken, diğer yandan da toplumun yenileşmesine öncülük etmektedir (Özdemir, 2000; s. 8-9). Fer (1999)'e göre, gelişimin odak noktasını oluşturan okullar temelde bireylerin gelişimini sağladığı için okulun gelişimi, toplumun gelişiminden ayrı düşünülemez, bu sebeple okullar için özlenen, istenen bir gelecek yaratarak okulların geleceğini şekillendirebilmek; yöneticiler, öğretmenler, öğrenciler, aileler ve toplumun birlikte çalışması ile mümkündür (akt. Yıldırım, 2013; s. 361). Bu noktada, "kapasite" ve "kapasite geliştirme" kavramları önem kazanır. Eğitimde kapasite, bir eğitim kurumun belirlenen hedeflerine ulaşabilme yeteneği olarak ifade edilirken; kapasite geliştirme konusuna okul açısından bakılacak olursa kavramın, okul yöneticileri, öğretmenler, yardımcı hizmetler grubunda çalışanlar, aileler, öğrenciler ve toplumun farklı kesimleri de dahil olmak üzere eğitimin tüm paydaşlarının okul iklimini geliştirmek ve okulun performansını artırmak için sergilemiş oldukları çabaların bütünü olduğu söylenebilir (Özdemir, 2012; s. 4). Okullarda öğretim kapasitesinin birbirine bağlı iki temel özelliği vardır. Bunlar: okulda öğretim etkinliğini artırmayı sağlayan kaynaklar ve bilgi oluşturma ile mesleki öğrenmeyi sağlayacak olan sosyal süreçlerdir (Adams, 2013; s. 3).

Okullarda öğrenme kapasitesini artıran sosyal bir süreç olan "kolektif güven" bu araştırmanın temel noktalarından birini oluşturmaktadır. Kolektif güven, köklü algıları olan ve başka bir grup ya da bireyin güvenilirliğinden etkilenen durağan bir grup özelliği olarak tanımlanabilir 
Güçlü, N., Tepe, N., \&Duman, Ș. (2017). Öğretim kapasitesinin sosyal bir göstergesi olarak kolektif güven: Nitel bir araşturma. Journal of Human Sciences, 14(2), 1284-1297. doi:10.14687/jhs.v14i2.4492

(Forsyth, vd. 2011; s. 22). Açıklık, dürüstlük, yardımseverlik, yetkinlik ve güven temeline dayanmaktadır (Hoy and Tschannen-Moran, 1999; s. 186).

Kolektif güven kavramını derinlemesine analiz etmeden önce, güven kavramını incelemek faydalı olacaktır. Fukuyama'ya göre ekonomik ve toplumsal performansı geliştiren sosyal sermayenin temelinde güven duygusu vardır (Şan, 2007; s. 294). Etkili ve işlevsel örgütlerde güven, gittikçe hayati bir unsur olarak görülmektedir (Tschannen- Moran ve Hoy, 1998; s. 334).

Yapılan araştırmalarda güven konusunun başlangıçta psikologlar, sosyologlar, siyaset bilimcileri ve ekonomistlerin ilgisini çektiği, daha sonra örgüt teorisi, yönetim ve örgütsel davranış alanlarındaki araştırmalara konu olduğu görülmektedir (Asunakutlu, 2006; s. 18). Literatürde güven kavramı için farklı tanımlar kullanılmıştır. Bahsedilen güven türleri, aynı fenomeni kısmen veya tamamen açılarken bile bazen farklı olarak adlandırılmaktadır (Strier and Katz, 2016; s. 367). Güven, toplumsal yapıdaki değişimleri bireylerarası ilişkiler, büyük toplumsal hareketler veya ekonomik ilişkiler temelinde inceleyerek elde ettikleri sonuçlarla toplumu anlama biçimine yön veren araştırmacılar tarafindan anahtar kavram olarak kullanılmaktadır (Özen, 2003; s. 185). Güveni; bir kişinin başka bir kişinin sözlerinden, davranışlarından ve kararlarından emin olması ve bunlara göre hareket etme istekliliği (McAllister,1995; s. 25-26), bir tarafin karşı taraftan kişisel olarak yarar göreceğine veya en azından istismara ya da zarara uğramayacağına yönelik olumlu beklenti içinde olma özelliği (Perks ve Halliday, 2003; s. 339) olarak tanımlamak mümkündür.

Baier "Güven Güvensizlik" adlı makalesinde güvenin değerinin aynen atmosferdeki havanın değerinin eksildiğinde ya da kirlendiğinde fark edileceği gibi en çok kaybettikten hemen sonra anlaşılacağını belirmiştir (Baier, 1986; s. 234). Güven genellikle bir inanç olarak değil bir eylem olarak düşünülür (Holm ve Nystedt, 2010; s. 28); bir kişinin risk veya zayıllık içeren bir durumda başka bir tarafla olan ilişkisini nasıl anladığını gösteren bir psikolojik durumdur (Dirks ve Ferrin, 2001; s. 10). Önemli bir kültürel değer olarak örgütsel yapıların özellikleri üzerinde etkili olan güven, yüksek düzeyde olduğunda, merkezileşmenin azalmasına, gevşetilmiş, içselleştirilmiş denetim, bağlılık duygularının oluşmasına neden olurken güven azlığı ise, merkezileşmeyi artırmakta, katı dışsal denetimi devreye sokmaktadır (Sargut, 2001; s. 140).

Sosyal sermayenin ana öğesi olan güven, örgüt içinde ilişkileri bir arada tutan temel yapıştırıcı olarak görev yapar. Güven olmaksızın hiçbir kurum hedefini gerçekleştiremeyeceği gibi hiçbir şeyi iyi işletemez. Güven etkili ilişkilerin önemli öğelerinden birisi olduğu için örgüt içinde bireylerin karşlıklı güven duyması yaşamsal bir durumdur. Bu bağlamda örgütsel güven kavramının ve örgütsel güvenin yapısının detaylı biçimde anlaşılması örgüt içi güvenin olumlu sonuçlarından faydalanabilmek için önem taşımaktadır (İşcan ve Sayın, 2010; s. 196).

Örgütler açısından vazgeçilmez bir unsur olan güven, temel girdisi ve çıktısı insan olan, eğitim örgütlerinde, işbirliğinin ve eşgüdümün sağlanması, güvene dayalı bir okul atmosferinin oluşturulması, öğrenmelerinin gerçekleşmesi açısından hayati önem taşımaktadır; bu sebeple yönetici, öğretmen, öğrenci ve veliler arasında güvene dayalı ilişkiler geliştirilmeden, okullarda eğitsel amaçlara ulaşılmasının ve öğrenci başarısının sağlanmasının oldukça güç olduğu söylenebilir (Özer ve Atik, 2014; s. 89). Çünkü bireyler arasında ya da okul içinde var olan güven ya da güvensizlik düzeyi okullardaki ilişkilerin niteliğini belirleyen kilit unsurlardan biridir (Özer, vd. 2006; s. 107). Yüksek güven düzeyi okul etkililiğini artırır, akademik başarıya etki eder ve tüm okul paydaşları arasındaki iş birliğini önemli ölçüde etkiler (Mitchell ve Forsyth, 2004, s. 17). Hoy (2012; s. 78) okulda güvenin, diğer şahıs veya grupların sözlerine güvenebileceğine ayrıca okulun menfaatleri doğrultusunda hareket edeceğine dair ortak bir inanç olduğunu iddia etmektedir.

Kolektif güven, okul profesyonellerini, eğitim süreçleri ve uygulamalarının öğrenci öğrenimi ve gelişimi üzerindeki etkilerini anlamak için bilgi paylaşımı ve keşfetme motivasyonunu sağlar (Adams, 2013; s. 6). Kolektif güven, "iyi okul” kavramının önemli bir yap1 taşıdır (Forsyth vd 2011; s. 86). Kolektif güven, uygulayıcıların ve akademisyenlerin etkili bir performans için hayati bir kaynak olarak gördükleri bir okul özelliği olup; okullarda olumlu bir performans kültürü oluşmasına katk1 sağlar ve güvenin her bir çeşidi öğretme ve öğrenme şartlarını benzersiz bir biçimde şekillendirir (Adams and Forsyth, 2013; s. 1-2). Öğretmenler arasında mesleki topluluğun en güçlü 
Güçlü, N., Tepe, N., \&Duman, Ş. (2017). Öğretim kapasitesinin sosyal bir göstergesi olarak kolektif güven: Nitel bir araştırma. Journal of Human Sciences, 14(2), 1284-1297. doi:10.14687/jhs.v14i2.4492

kolaylaştırıcısı güvendir, öğretmenler birbirine güvenip sayg1 duyduklarında işbirliğini ve yansıtıc1 diyalogu destekleyen güçlü bir sosyal kaynak oluşur (Bryk vd., 1999; s. 254). Meslektaş arası güven öğretmenlerin zor durumlarda birbirlerine güvenebileceklerine dair inancıdır, öğretmenler arasında meslektaş bütünlüğünün güveni söz konusudur (Hoy ve Kupersmith, 1985; s. 2).

Güven kavramına ilişkin farklı tanımlar olmasına rağmen, özellikle okullarda kolektif güvenin açılanmasında Hoy ve Tschannen-Moran tarafindan önerilen güvenirlik, yardımseverlik, yetkinlik, dürüstlük, açıklık temeline dayanan model kabul edilmektedir (Hoy ve Tschannen-Moran, 1999; s. 186). Güvenirlik; bireylerin eylemlerinin sözleriyle tutarlı olması ve bireylerin davranışlarının tahmin edilebilirliği; yardımseverlik, birinin iyi olduğuna, önemsenen bir şeyin güvenilen kişi ya da grup tarafindan korunacağına ya da bir tarafin diğer tarafin yararına iyi şeyler yapacağına olan inancı; yetkinlik; bireyin hem teknik hem de kişisel bilgi ve becerisi; dürüstlük; bireyin söz ve eylemlerinin tutarlı olması ve kişinin eylemlerinin sorumluluğunu kabul etmesi; açıklık; bilginin başkalarıyla serbestçe paylaşılma derecesi olarak ifade edilebilir (Akt. Özer ve Atik, 2014; s. 89).

Okullar, kendi içinde ilişkisel ağlar, koordineli yapılar, dayanışma, zayıf noktalar ve davranışsal beklentilerle tanımlanan sosyal sistemler olup (Adams and Forsyth, 2013; s. 2); insanlardan meydana gelen topluluklardır (Şişman, 2014; s. 290). Güven bireylerin görevlerine daha çok odaklanmalarını, dolayısıyla daha etkili çalısıı, daha etkili öğrenmelerine olanak tanır. Verimli ilişkiler, dolayısıyla verimli okullar inşa eder (Tschannen- Moran ve Hoy, 1998; s. 341). Okullardaki güven, işbirliğini artırmada (Tschannen-Moran, 2001), açık okul kültürleri oluşturmada (Hoffman, Saho, Bliss ve Hoy, 1994), grup bağlllığını teşvik etmede, okul başarısını (Goddard, vd. 2001) ve okul kalitesini artırmada (Hoy ve'Tschannen-Moran, 2003 ) çok önemli etkiye sahiptir (akt. Koşar ve Yalçınkaya, 2013; s. 604). Öğretmenler, öğrenciler, okul yöneticileri ve velilerin birbirlerine güven duydukları okullar daha etkili olmaktadır (Hoy ve Miskel, 2010; s. 191-192).

Eğitim örgütleri olan okulların etkili ve verimli olabilmesi, belirlenen amaçlara ulaşılabilmesi, öğrencilerin etkili bir şekilde öğrenim görebilmeleri için, okulu oluşturan tüm paydaşların işbirliği ve uyum içerisinde çalışmaları paydaşlar arası güven ilişkileri ile ilgilidir (Özer vd., 2006; s. 107). Bireyler arasındaki ilişkilerin niteliğinin artırılması ile örgüt işleyişinin etkilenebileceği kabul edildiği için; okullarda güven ortamına dayalı bir kültürün oluşturulması eğitimin amaçlarına ulaşmasını kolaylaştrabilecektir (Akın, 2015; s. 175).

\section{Araştırmanın Amacı}

$\mathrm{Bu}$ çalışmanın temel amacı, okul yöneticilerinin okullarındaki kolektif güvene ilişkin görüşlerini belirlemektir.Ayrıca bu amaç doğrultusunda okul yönetimi sürecinde güvenilirlik, açıklık, dürüstlük, yardımseverlik ve yetkinlik gibi faktörlerin incelenmesi de alt amaçlar olarak belirlenmiştir.

Araştırmanın amacı doğrultusunda aşağıdaki sorulara cevap aranmıştır:

1. Güven kavramını nasıl tanımlarsınız?

2. Yönetici olarak risk alır mısınız?

3. Öğretmenleriniz, öğrencileriniz ve velilerinize güvenir misiniz? Dürüst olduklarına inanıyor musunuz?

4. Eğitim ile ilgili yapılması gereken bir şey olduğunda yardımseverlik anlamında;

-Ögretmenler nasildır?

-Öğrenciler nasıldır?

-Veliler nasildir?

5. Okulunuzda bilgi paylaşımı nasıl gerçekleşmektedir? Açıklı yöntemini benimser misiniz?

6. Okulunuzdaki öğretmenlerinizin yetkinliği hakkında ne düşünüyorsunuz? Bir işi yaptırmak için informal ilişkilerinizi mi ön planda tutarsınız yoksa işinde yetkin (uzman-becerikli) olan kişileri mi tercih edersiniz? 
Güçlü, N., Tepe, N., \&Duman, Ş. (2017). Öğretim kapasitesinin sosyal bir göstergesi olarak kolektif güven: Nitel bir araştırma. Journal of Human Sciences, 14(2), 1284-1297. doi:10.14687/jhs.v14i2.4492

7. Okulunuzda bütüncül bir güven ortamı sağlandığında nasıl neticeler alınmaktadır? Eğitim sürecinde rol alan paydaşların (yönetici-öğretmen-öğrenci-veli) birbirine güven duyması, eğitim ortamı olan okullara nasıl yansımaktadır?

\section{Yöntem}

\subsection{Araştırma Modeli}

Araştırma, nitel araşturma desenlerinden biri olan "olgu bilim” deseni kapsamında yürütülmüştür.Olgu bilim çalışmalarında genellikle farkında olunan ancak derinlemesine ve ayrıntılı bir anlayışa sahip olunmayan olguların ortaya çıkarılması ve yorumlanması amaçlanmaktadır (Yıldırım ve Şimşek, 2008; s. 72).

\section{2. Çalışma Grubu}

Araştırmanın çalışma grubunu basit tesadüfi örneklem yoluyla seçilen 10 okul yöneticisi oluşturmaktadır.Okul yöneticilerinin 3'ü kadın, 7'si ise erkek olup; tamamı devlet ortaokullarında görev yapmaktadırlar.

\subsection{Verilerin Toplanmas1}

Çalışmanın amacı 1şı̆̆ında nitel veri toplama araçlarından biri olan yarı yapılandırılmış görüşme formu kullanılmıştır.Görüşme formu sekiz açık uçlu sorudan oluşmuştur.İçeriğine göre bazı sorular sonda soruları ile desteklenmiştir. Sorular alanla ilgili literatür taraması yapıldıktan sonra beş tema belirlenerek hazırlanmıştır. Görüşme formunun geçerliliğini saptamak amacıyla uzman görüşüne başvurulmuş ve alınan uzman görüşleri doğrultusunda form yeniden düzenlenmiştir. Kavramsal çerçeveye uygun olarak hazırlanan sorular 10 okul yöneticisine görüşme tekniği ile uygulanmıştır.Katılımcılarla, gönüllülük esasına dayalı görüşmeler gerçekleştirilmiştir.Görüşme esnasında amaçtan sapmamaya çalısıllarak notlar alınmış, cevapların geniş ve kapsamlı olmasına gayet edilmiştir.Görüşmeye katılamayanlara mail yoluyla açık uçlu sorular gönderilerek cevaplar alınmıştır.Toplanan veriler elektronik ortama aktarılarak kodlanmıştır.Okul yöneticileri Y1, Y2, Y3...şeklinde isimlendirilmiştir.Toplanan veriler, içerik analizi ile çözümlenmiştir.Araştırmanın güvenirliğinin sağlanması açısından, her iki araştırmacı tarafından ayrı ayrı kodlama yapılmıştır.

\subsection{Verilerin Analizi}

Elde edilen veriler içerik analizi tekniği kullanılarak analiz edilip yorumlanmıştr.İçerik analizi hacimli olan materyali alarak temel tutarllıkları ve anlamları belirlemeye yönelik herhangi bir nitel veri indirgeme ve anlamlandırma çabası girişimlerini ifade etmek için kullanılır (Patton, 2014; s.453).

\section{Bulgular ve Tartışma}

$\mathrm{Bu}$ bölümde, araştırmanın temel amacına uygun olarak yöneticilerden toplanan verilerin çözümlemeleri doğrultusunda ortaya çıkan bulgulara yer verilmiştir.Kavramsal çerçeveye uygun olarak daha önceden belirlenen kodlamalar yapilarak, analiz edilen ifadeler tablolar halinde gösterilmiştir.Aynıca elde edilen sonuçlar konuyla ilgili yapılmış literatürde geçen çalışmaların sonuçları ile karşılaştırlarak tartışmaya yer verilmiştir. 
Güçlü, N., Tepe, N., \&Duman, Ş. (2017). Öğretim kapasitesinin sosyal bir göstergesi olarak kolektif güven: Nitel bir araşturma. Journal of Human Sciences, 14(2), 1284-1297. doi:10.14687/jhs.v14i2.4492

Tablo 1: Güven kavramına ilişkin cevapların incelenmesi

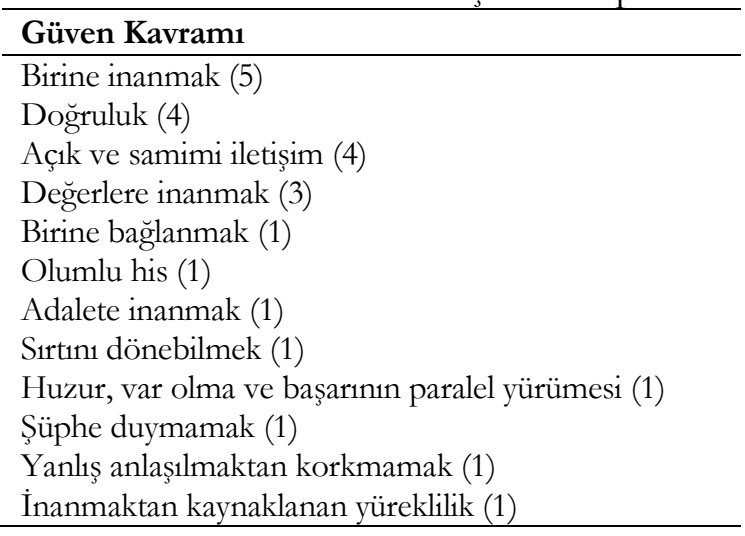

Yöneticilerin güven kavramına ilişkin görüşlerinin incelendiği Tablo 1'e göre güven; daha çok birine ve değerlere inanmak, doğruluk, açık ve samimi iletişim olarak ifade edilirken; birine ve adalete inanmak, olumlu hisler, şüphe duymamak, yanlış anlaşlmaktan korkmamak, birine inanmaktan kaynaklanan yüreklilik ve birine sırtını dönebilmek olarak da ifade edilmiştir. Butler (1991) çeşitli şirketlerden 84 yöneticiyle gerçekleştirdiği çalışmasında güven için tutarlılık, basiret, adillik, bütünsellik, sadakat, açıklık, bulunabilirlik, yetkinlik, sır tutabilme ve sözünü tutabilme şartlarını önermiştir. Hoy ve Tschannen-Moran (1999) çalışmalarında ise güven; bir bireyin ya da grubun karşısındaki birey(ler)in yardımsever, güvenilir, uzman, dürüst ve açık olduğuna dair inançlarına dayanarak, karşısındaki birey ya da gruba savunmasız kalmaya istekli olmaları olarak tanımlanmıştır.

Tablo 1a: Yöneticilik-güven arasındaki ilişkiye dair cevaplann incelenmesi

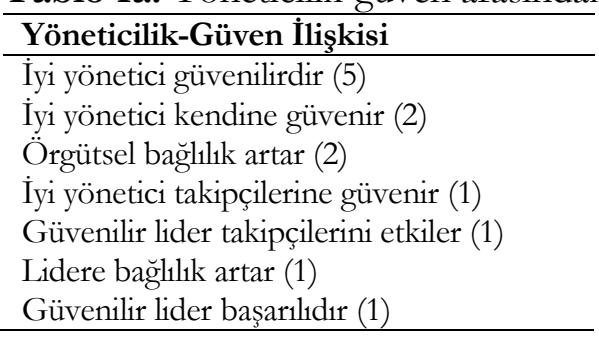

Güven kavramına ilişkin cevapların incelendiği birinci sorunun sonda sorusu olan yöneticilik güven arasındaki ilişkinin nasıl algılandığına ilişkin yöneticilerin cevaplarının incelendiği Tablo 1a'ya göre, iyi yönetici güvenilirdir, kendine ve takipçilerine güvenir, başarılıdır.Ayrıca yönetici güvenilir olduğunda takipçilerini etkiler, lidere bağlllık ve örgütsel bağlllık artar.

Bu konuda Y5 şu görüşleri ifade etmiştir:

"Ë̆er bir insana güvenirsem o insann fikirlerinin beni etkilemesine karşı bende oluşan dwvarlarn doğal olarak kaldirmm.Zaten lider rublu insanlar ileri görüslü davranarak güven duygusu olustururlar."

Bu konuda Y8 şu görüşleri ifade etmiştir:

"Okullarda güven kavramm okulun değerlerine inanmak șeklinde tammlayabilirim.Lidere güven duygusunun artması lidere bağhliğgn artmasmo böylece okulun amaçlarma en yü̈esek düreyde ulaşlmasinı sağlar.Cünkü okullarda yönetici lider misyonuyla çallşanlarn işlerine motive olmalarm kolaylastıracak şartlarn oluşturulmasim sağlar. İi ve başarli okullardan farkh olarak, çatısmann yoğun olduğu ve ekip rubunun

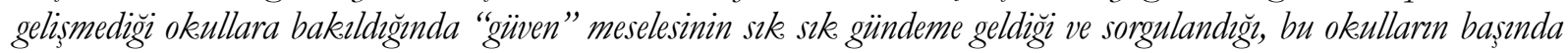
olan kisilerin ise liderlik vasıflarndan uzak olduğu görülï̈or. Bu nedenle güven simrlarm aræu edilen güven düreyine yükeseltmek, okulun güglï yönlerine odaklanmak, sinirllhklarn farkinda olmak ve güclü yönlerin ortaya çlkartıldiğg farkh yeteneklere sabip iyi çalşsma gruplar olușturmak gerekiyor. "

Tschannen-Moran ve Hoy (2000) araştırmasına göre çalışanların yöneticilerinin sözlerinden, davranışlarından ve kararlarından şüphe duymaması lider ve üye arasındaki etkileşimin kalitesine 
Güçlü, N., Tepe, N., \&Duman, Ş. (2017). Öğretim kapasitesinin sosyal bir göstergesi olarak kolektif güven: Nitel bir araşturma. Journal of Human Sciences, 14(2), 1284-1297. doi:10.14687/jhs.v14i2.4492

bağlıdır. Çalışanlar, yöneticileriyle etkileşimlerinde aralarındaki iletişimi açık ve doğru buluyorlarsa yöneticilerine güven duyulabileceğine inanmaktadırlar.

Tablo 2: Risk Alma kavramına ilişkin cevapların incelenmesi

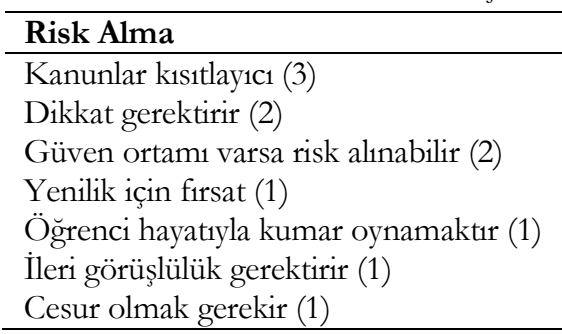

Tablo 2'ye göre okul yöneticileri risk alma konusunda kanunların kısıtlayıcı olduğunu ve dikkatli olunması gerektiğini, öğrenci hayattyla kumar oynamak anlamına gelebileceğini belirtmişlerdir. Ayrıca güven ortamı söz konusu olduğunda risk alınabileceğini, cesur ve ileri görüşlü olmak gerektiğini ifade eden yöneticiler de vardır.

Bu konuda Y1 şu görüşleri ifade etmiştir:

"Kanun yönetmelikler siz̨in risk almanız kisitlyyor. Siz ne kadar risk alrrsanz alın riskin sonunda sorun çlkmamıssa problem yok. Risk alir başarrsanı biç bir ödül ve aferin beklemeyin kendi aldiğmı hąla

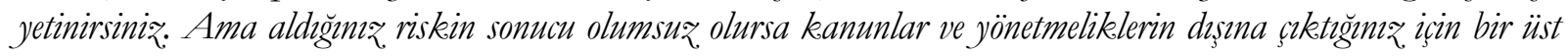

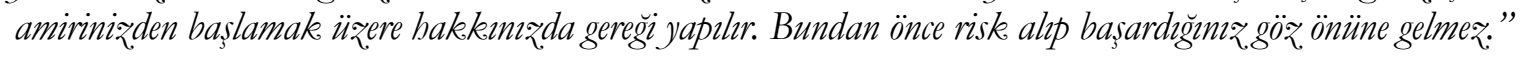

Tablo 3: Güven derecesine ilişkin cevapların incelenmesi

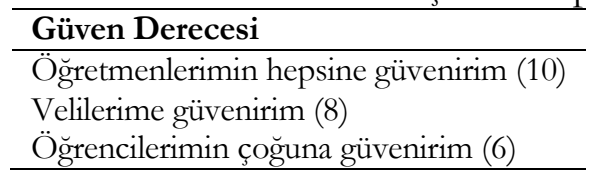

Okul yöneticilerinin algıladıkları güven derecesinin incelendiği Tablo 3'e göre yöneticilerin tamamı öğretmenlere güvenmektedir.Büyük çoğunluğu velilere ve bir kısmı da öğrencilerine güvendiğini ifade etmişlerdir. Adams (2014) çalışmasında öğretmenlerin öğrenciye karşı güven duygusunun olduğu bir kültüre sahip olan okulların bireysel öğrenmeyi ve akademik başarıyı teşvik etmede daha etkili olduklarını tespit etmiştir.

Bu konuda Y2 ş görüşleri ifade etmiştir:

"Bașlangus olarak hepsine tam güvenerek ișe bașlarm.Daha sonra kişiler yaptıklarn eylemlerle bendeki bu durumlarm korur yada kaybederler."

Tablo 3a: Dürüstlük derecesine ilişkin cevapların incelenmesi

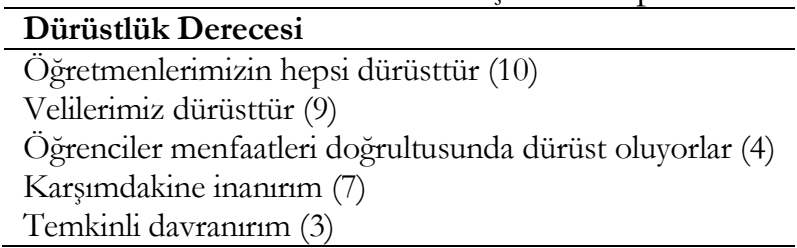

Okul yöneticilerinin alg1ladıkları dürüstlük derecesinin incelendiği Tablo 3a’ya göre yöneticilerin tamamı öğretmenlerin dürüst olduklarını belirtmişlerdir. Yöneticilerin büyük çoğunluğu velilerin dürüst olduğunu, bir kısmı ise öğrencilerin menfaatleri doğrultusunda dürüst davrandıklarını belirtmişlerdir. Yöneticilerin çoğu dürüstlük konusunda karşısındakine inandıklarını, bir kısmı ise temkinli davrandıklanını ifade etmişlerdir. Hoy ve Miskel (2010)'e göre öğretmenler, öğrenciler, okul yöneticileri ve velilerin birbirlerine güven duydukları okullar daha etkilidirler. 
Güçlü, N., Tepe, N., \&Duman, Ş. (2017). Öğretim kapasitesinin sosyal bir göstergesi olarak kolektif güven: Nitel bir araşturma. Journal of Human Sciences, 14(2), 1284-1297. doi:10.14687/jhs.v14i2.4492

Tablo 4: Yardımseverlik kavramına ilişkincevapların incelenmesi

Yardımseverlik

Öğretmenlerin hepsi yardımseverdir (9)

Öğrenciler ödül varsa yardım ederler (4)

Veliler ilgisizdir (3)

Veliler bilgilendirilirse yardımseverdir (3)

Öğrenciler yardımseverdir (6)

Veliler kısmen (2)

Veliler her şeyi devletten ve öğretmenden bekler (2)

Tablo 4'e göre okul yöneticilerinin büyük çoğunluğu öğretmenlerin yardımsever olduklarını, bir kısmı ise öğrencilerin de yardımsever olduklarını düşünmektedirler.Bazı yöneticilere göre öğrenciler ödül karşllığında yardımsever davranmakta, velilerin ise bilgilendirildikleri ölçüde yardımsever davrandıklarını belirtmişlerdir.Bazı velilerin ise ilgisiz oldukları, her şeyi devletten bekledikleri belirtilmiştir.

Bu konuda Y4 şu görüşleri ifade etmiştir:

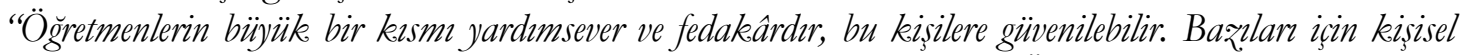
öncelikleri ve cıkarlar onlarn fedakâr ve yardım sever olmalarmm önünde engeldir. Öğrencilerin de tamamma yakın fedakâr ve yardımseverdir.Bu konuda çoğu güvenilirdir, düssünmeden bu tür işlere dâbil edilebilir.Velilerin bir kismı yardımsever ve fedakârdır, çoğgnlukla yardımı ve fedakârlhğg devletin ve ögretmenlerin yapmasm ister.Çok güvenilir olduklar söylenemez, büyüle bir kısmmmn.Belki doğru iletişim stratejileri gelistirerek okuldaki bu tür etkinliklere yardim etmeleri sağlanabilir."

Tablo 5: Bilgi Paylaşımına ilişkin cevaplarınincelenmesi

\begin{tabular}{l}
\hline Bilgi Paylaşımında Açıklık \\
\hline Herkes bilmesi gerektiŏini bilir (6) \\
Adil, açık ve şeffaf oluyoruz (2) \\
Kapalı kapılar ardında olmam (2) \\
Bir ayna vazifesi görürüm (1)
\end{tabular}

Okul yöneticilerinin bilgi paylaşımına ilişkin cevapları incelendiğinde yöneticilerin yarıdan fazlasının herkesin bilmesi gerektiğini bildiğini, bir kısmı iseaçık ve şeffaf olduklarını, yöneticinin kapalı kapılar ardında olmadığını, ayna vazifesi görerek bildiklerini paylaştı̆̆ konusunda görüş belirtmişlerdir. Genel görüşler incelendiğinde okul yöneticilerinin açıllık ilkesini benimsedikleri söylenebilir.

Bu konuda Y6 şu görüşleri ifade etmiştir:

"Haftahle koordinasyon toplantımı̨da; ögrenci, veli ve ögretmen sorumlular ile binanm sorumlular


ya da ögrenciye yapılacak duyurularda idareciler haberdar edilip, övgüler aleni yapulurken sorunlar birebirde balledilmeye çallşllir.Toplulukta eleştiri ortammdan kaçnmak gerekir.Topluluk psikolojisi baz̧en kuruma zarar verebilir.”

Tablo 6: Yetkinlik kavramına ilişkin cevapların incelenmesi

\begin{tabular}{l}
\hline Yetkinlik \\
\hline İşin ehlini tercih ederim (6) \\
Yerine göre her ikisini de tercih ederim (2) \\
İnformal ilişsileri önemserim (2) \\
\hline
\end{tabular}

Tablo 6’ya göre okul yöneticileri yetkinlik konusunda genel görüşü işin ehlini tercih ettikleri yönündedir. İnformal ilişkileri önemseyen, yerine göre her ikisini de tercih eden yöneticiler de bulunmaktadır.

Bu konuda Y1 şu görüşleri ifade etmiştir: 
Güçlü, N., Tepe, N., \&Duman, Ş. (2017). Öğretim kapasitesinin sosyal bir göstergesi olarak kolektif güven: Nitel bir araşturma. Journal of Human Sciences, 14(2), 1284-1297. doi:10.14687/jhs.v14i2.4492

"Her işi o işin ebli yapmalidır.Buna yöneticilike ve ögretmenlikte dâbil. Ĕğer ebli değil ise çıtıdan, üründen fazla bir şey beklemeyin. Bir işi yapturrken genelde ișinde yetkin olan kişileri tercih ederim. Tabi bulamadrğımı. zamanlarda oluyor o zamanda ișimizi aksatmayacak şekilde işimizi yerine getirecek sekilde düzenimizi kurmak için diğer kişilerden de yararlanyoruz. Yarm hoca dinden yarm doktorda candan eder derler. Ben yarm ögretmen de bayattan eder diyorum."

Bu konuda Y7 şu görüşleri ifade etmiştir:

"Yapacă̆ımı işleri yetkin kişiler yaparsa sonuc iyi olabilir.Yapacağımı işleri informal ilişkileri de göz. önüne alarak yaparsak sonuc yine iyi olabilir. Ama yapacağımı işleri hem yetkin kişilerle hem de formal ve informal iliskileri de göz önünde bulundurup bir denge yakalarsak ve bir hava olușturursak kesin başarya ulaşı."

Tablo 7: Güvenin neticesine ilişkin cevaplann incelenmesi

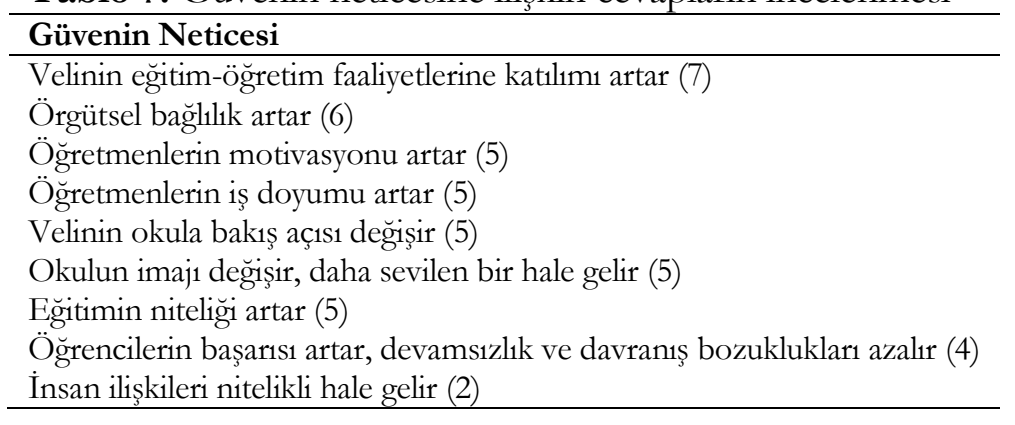

Okul yöneticilerinin okulda güven ortamı sağlandığında nasıl neticeler alınacağına ilişkin görüsslerinin incelendiği Tablo 7'ye göre, güven olan ortamlarda velilerin eğitim-öğretim faaliyetlerine katılımı artar ve okula bakış açısı değişir. Öğretmenlerin motivasyonu ve iş doyumu artar. Öğrenciler açısından düşünüldüğünde başarı artar, devamsızlık ve davranış bozuklukları azalır. Genel olarak ise örgütsel bağlıllı̆̆ın arttı̆̆1, eğitimin niteliğinin arttığ1, insan ilişkilerinin nitelikli hale geldiği, okulun imajının değiştiği ve daha sevilen bir hale geldiği görülmektedir.

Bu konuda Y3 şu görüşleri ifade etmiştir: gelistivir."

"Güven ile gelişimi doğru oranthl görüyorum.Güven üretkenliği ve ferablĭg getirir.Herkes gelisir ve

Bu konuda Y4 şu görüşleri ifade etmiştir:

"Güven örgütün amaçlarmm ve hedeflerinin gerçekleșmesi için önemlidir. Yönetici ve öğretmenlerin karşsllkle olarak birbirinin iyi niyetine inanması ve sü̈phe, belirsizlik, adaletsizlik, yanhlik gibi güven sarsan olumsuz, ortamm olmaması ögretmenlerin iș doyumu, okula bağhlhklar ve motivasyonu artmaktadır ve daha verimli olmaktadirlar. Öğrencilerin de okula bağhllklar, kendilerine güven duyulduğunda basarma istekleri artmakta, davranıs bozukluğu ve devamsızhle oranlar azalmaktadir.Veliler de gïven ortammdan dolayn olusan "birim okulumuz" algisı ile yönetici ve ögretmenlerin eğitim etkinliklerine destekleri, katıllmlar artmaktadir.Maddi ya da manevi bir destek istenildiğinde veli o isteğin ögrencinin yararna olduğu noktasinda ș̈̈pheci davranmamaktadır."

Bu konuda Y5 şu görüşleri ifade etmiştir:

"Adanmuşl̆ğa kadar yolu var bunun.Öğrenci, ögrrenci olmaktan çııı ustasina hayran bir çırak olur.Ve ustasmdan gördügünü alp gelistirerek boynuz kulağ geçer misali toplumu bir adım daha ileri götürür.Veli okulun bir parçası olmaya başlar.Okul için yaptiğ isler angarya olmaktan gıkar.Toplum bizmeti yaptiğm düşünür.Farkinda olmadan bir ögretmen edasylla olumlu davranıslar etrafina yaymaya bașlar.V elinin yü̈zü gülerse

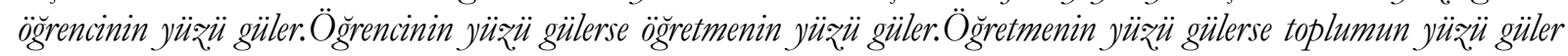
vesselam."

Yapılan çalışmalarda güvenin; okulların performansını artırmada önemli olduğu (Bryk and Schneider, 2002), sürekli gelişim çabalarını desteklediği (Seashore Louis, 2007), öğretmenleri bir arada tutan bir tutkal görevinde olduğu (Meier, 2002), okullarda meslektaşlar arası güven ile ebeveyn güveni birleştirildiğinde okul etkililiğini artırdığı (Forsyth, Barnes ve Adams, 2006), işbirliği, performans değerlendirme, amaç oluşturma, liderlik, takım ruhu, örgütselbağlılık ve iş doyumuna 
Güçlü, N., Tepe, N., \&Duman, Ş. (2017). Öğretim kapasitesinin sosyal bir göstergesi olarak kolektif güven: Nitel bir araşturma. Journal of Human Sciences, 14(2), 1284-1297. doi:10.14687/jhs.v14i2.4492

katkıda bulunma gibi örgütsel faaliyetler vesüreçlerde önemli rol oynadı̆̆ (Huff ve Kelley, 2003) belirlenmiştir. Güven algısının yüksek olduğu örgütlerde açık örgüt kültürünün daha kolay benimsendiği, iletişim kanallarının açık olduğu, iş birliği davranışının daha yüksek düzeyde olduğu görülmüştür (Polat, 2007).

\section{Sonuç}

$\mathrm{Bu}$ araştırmada kolektif güven; yardımseverlik, güvenilirlik, yetkinlik, dürüstlük ve açıklık olmak üzere toplam beş boyutta incelenmiştir. Araştırma verilerinden analiz edilmesiyle bu beş boyutta şu sonuçlanı çıkarmak mümkündür:

Yardimseverlik boyutunda; ögretmenler hangi konu olursa olsun fedakar davranmakta hiçbir karşılık beklemeden gerek öğrenciler gerekse de okul için özverili çalışmaktadırlar.Öğrencilerin büyük bir çoğunluğu yardımseverlik davranışını sergilemekte ancak bazı menfaatleri doğrultusunda yardımsever davranmaktadır.Veliler ise yardımseverlik davranışını çok sergilememektedirler.Büyük bir kısmı eğitime karşı ilgisiz davranmakta ya da her şeyi devletten-öğretmenden-okuldan beklemektedir.Ancak küçük bir kısmı eğitim için, çocukları için yardımsever davranmakta; yine küçük bir kısmı da ilgili konularda gerekli ve yeterli şekilde bilgilendirildiği sürece yardımsever davranmaktadır.

Güvenirlik boyutunda; okul yöneticileri en güvenilir kişilerin ögretmenler olduklarını, velilerin isetamamına yakınının ve ögrencilerin çoğunun güvenilir olduklarını belirtmişlerdir.

Dürüstlük boyutunda; okul yöneticileri en dürüst kişilerin öğretmenler olduklarını, velilerin çoğunun dürüst olduklarını, öğrenci ise zaman zaman menfaatlerine göre dürüstlük derecelerinin değiştiğini ifade etmişlerdir.

Yetkinlik boyutunda; okul yöneticilerinin çoğu bir işi yaptırırken o işte yetkin olan kişileri tercih edeceğini belirtmiştir.Kalan kısmı ise informal ilişkileri ön planda tuttuğunu bazen de duruma göre her iki yöntemi de kullanabileceğini belirtmiştir.

Açıklık boyutunda; okul yöneticileri kanunların sınırlayıcılı̆̆ı doğrultusunda hareket ettiklerini, herkesle gerektiği kadar bilgi paylaşımında bulunduklarını ifade etmişlerdir. Ancak kapalı kapılar ardında olmadıklarını, her zaman öğretmen, öğrenci ya da velilerle iletişime açık olduklarını; açık, net ve şeffaf bir yönetim anlayışı benimsediklerini ifade etmişlerdir.

Araştırmanın sonuçlarına göre görüşme yapılan okul müdürlerinin okullarında, kolektif güven anlayışının benimsendiği söylenebilir.Genel bir değerlendirme yapıldığında ise; iyi bir yöneticinin aynı zamanda güvenilir bir yönetici olduğu, güvenilir bir yöneticinin, örgütsel bağlıllğın artmasına katk1 sağladığ1 söylenebilir.Kolektif güvenin sağlandığ1 okullarda eğitimin niteliğinin arttı̆̆, insan ilişkilerinin olumlu yönde geliştiği söylenebilir.

\section{6. Öneriler}

Okul yönetiminde tüm paydaşlar arasında (yönetici-öğretmen-öğrenci-veli) kolektif bir güven bağı kurulacak ortamlar oluşturulmalıdır.Bu ortamlarda paydaşların birbirini tanıması, karşlıklı olarak istek ve taleplerinin farkında olması sağlanmalıdır.Birbirine güvenen insanlar, aralarındaki duvarı yıkacak, iletişime açık hale geleceklerdir.Böylece eğitim-öğretim faaliyetlerinin niteliğini artırmak için severek ve özverili bir şekilde çalışacaklardır.

Dürüstlüğün en temel değerlerden biri olduğu öğrencilere sık sık vurgulanmalı, her zaman ve her koşulda doğruyu söylemek teşvik edilmelidir.Öğrencilerin yardımseverlik duygularını geliştirmek için çeşitli projeler geliştirilmeli, ancak karşılıksız yapılması gerektiği vurgulanarak, davranış haline getirilmelidir.Veliler ise teşvik edilerek, ilgili konularda bilgilendirilerek okula bağlllı̆̆1 artırılmalıdır.Bu amaçla çeşitli uygulamalı seminerler ya da etkinlikler düzenlenebilir.

Okullarda bilgi paylaşımı konusunda her seviyeye uygun bir yöntem izlenmelidir.Öğretmen, öğrenci ve veliler arasında farklılıklar olduğu gerçeği göz önünde bulundurulmalıdır.Ayrıca her okulun bulunduğu bölge ve kültür yapısı dikkate alınarak, bilgi paylaşımında en uygun yöntem tercih 
Güçlü, N., Tepe, N., \&Duman, Ş. (2017). Öğretim kapasitesinin sosyal bir göstergesi olarak kolektif güven: Nitel bir araşturma. Journal of Human Sciences, 14(2), 1284-1297. doi:10.14687/jhs.v14i2.4492

edilmelidir. Eğitim-öğretim ile ilgili yapılması gerekenlerde titizlik ve ehil olma durumu göz ardı edilmemeli, işler mutlaka uzmanına yaptırılmalıdır.

Kolektif güveni inşa ederken okulun lideri olarak ilk adımı okul yöneticisi atmalıdır.Yönetici okulun değişimini, gelişimini sağlamak ve eğitimin niteliğini artırmak için karşısındakine güven duyduğunu ona inandığını göstermelidir.Böylece kendilerine güvenildiğini gören öğretmen, öğrenci ya da veliler okula bir adım daha yaklaşacak ve sorumluluklarını isteyerek, severek yerine getireceklerdir.

\section{KAYNAKÇA}

Adams, C. M. (2013).Collective trust: A social indicator of instructional capacity. Journal of Educational Administration.(51)3, 363-382.

Adams, C. M. (2014). Collective student trust: A social resource for urban elementary students. Educational Administration Quarterly. (50)1, 135-159.

Adams, C. M. \& Forsyth, P. B. (2013).Revisiting the trust effect in urban elementary schools.The Elementary School Journal. 114(1), 1-21.

Asunakutlu, T. (2006).Çalışanlar ile yöneticiler arasında güven duygusunun araşturılması: turizm sektöründe bir uygulama.Dokuz Eylül Üniversitesi Sosyal Bilimler Enstitïsü Dergisi. 8(4), 16-33.

Akın, U. (2015). Okullarda örgütsel sinizm ve güven ilişkisinin incelenmesi: Öğretmenler bir araşturma. Ë̆itim ve Bilim.40(181), 175-189.

Baier,A. C. (1986). Trust and antitrust.Ethics. 96(2),231-260.

Bryk, A., Camburn, E., \& Seashore Louis, K. (1999). Professional community in Chicago elementary schools: Facilitating factors and organizational consequences. Educational Administration Quarterly.35, 751-781.

Bryk, A. S., \& Schneider, B. (2002).Trust in schools: A core resource for improvement. New York: Russell Sage Foundation.

Butler, J. K., Jr. (1991). Towards understanding and measuring conditions of trust: Evolution of a conditions of a trust inventory. Journal of Management. 17, 643-663.

Dirks, K.T. \& Ferrin, D.L. (2001). The role of trust in organizational settings. Organizational Science. 12(4), 450-467.

Drucker, P. (2011). Büyük değissimler çağında yönetim. Çev: Zülfü Dicleli. İstanbul: Optimist

Forsyth, P. B., Barnes, L. B., \& Adams, C. M. (2006). Trust-effectiveness patterns in schools. Journal of Educational Administration.44(2), 122-141.

Forsyth, P. B., Adams, C.M. \& Hoy, W.K. (2011).Collective trust: Why schools can't improve without it. New York: Teachers College.

Hoy, W. K. (2012). School characteristics that make a difference for the achievement of all students: a 40-year odyssey. Journal of Educational Administration.50(1), 79-97.

Hoy, W. \& Miskel, C. G. (2010).Eğitim Yönetimi: Teori, Araştırma ve Uygulama. (Çev. Ed.:Selahattin Turan). Ankara: Nobel.

Hoy W.K. \& Kupersmith W.J. (1985). The meaning and measure of faculty trust. Educational and Psychological Research, 5(1), 1-10.

Hoy, W. K. \& Tschannen-Moran, M. (1999). Five faces of trust: An empirical confirmation in urban elementary schools. Journal of School Leadership.9, 184-208.

Holm, H. J. \& Nystedt, P. (2010).Collective trust behavior. Scand. J. Of Economics.112(1), 25-53.

Huff, L. \& L. Kelley, (2003). Levels of organizational trust in individualist versus collectivist societies: A seven-nation study. Organization Science. 14(1), 81-90.

İşcan, Ö. F. ve Sayın, U. (2010).Örgütsel adalet, iş tatmini ve örgütsel güven arasındaki ilişkiAnkara Üniversitesi İktisadi ve İdari Bilimler Dergisi. (24)4, 195-216. 
Güçlü, N., Tepe, N., \&Duman, Ş. (2017). Öğretim kapasitesinin sosyal bir göstergesi olarak kolektif güven: Nitel bir araşturma. Journal of Human Sciences, 14(2), 1284-1297. doi:10.14687/jhs.v14i2.4492

Karip, E. ve Köksal, K. (1996).Etkili eğitim sistemlerinin geliştirilmesi.Kuram ve Uygulamada Eğitim Yönetimi. 2(2), 245-257.

Koşar, D. ve Yalçınkaya, M. (2013). Öğretmenlerin örgütsel vatandaşlık davranışlarının yordayıcıları olarak örgüt kültürü ve örgütsel güven.Kuram ve Uygulamada Eğitim Yönetimi, (Educational Administration: Theory and Practice). 19(4), 603-627.

McAllister, D. J. (1995).Affect-and cognition-based trust as foundations for interpersonal cooperation in organizations. Academy of Management Journal. 38(1), 24-59.

Meier, D. (2002). In schools we trust: Creating communities of learning in an era of testing and standardization. Boston: Beacon.

Mitchell, R. M. \& Forsyth, P.B. (2004). Trust, the principal, and student identification. A Paper Presented at the Annual Meeting of The University Council for Education Administration. Kansas City, Missour.

Özdemir, S. (2000).Eğitimde örgütsel yenileșme. Ankara: Pegem A.

Özdemir, S. (2012). Türk eğitim sistemi ve okul yönetimi. (Ed. Servet Özdemir). Ankara: Pegem A.

Özen, J. (2003). Örgütlere Duyulan Güvenin Anahtar Unsuru Olarak Örgütsel Adalet. (Ferda Erdem), Sosyal Bilimlerde Güven içinde, (s. 183-206). Ankara: Vadi.

Özer, N. ve Atik, S. (2014). Ortaokul ve lise öğrencilerinin okul müdürlerine güven düzeylerinin incelenmesi.Ahi Evran Üniversitesi Kırşehir Eğitim Fakültesi Dergisi (KEFAD). (15)3.87-106.

Özer, N., Demirtaş, H., Üstüner, M. ve Cömert, M. (2006).Ortaöğretim öğretmenlerinin örgütsel güven algilar1.Ege Ë̈itim Dergisi. (7)1, 103-12.

Patton, M. Q. (2014). Nitel araştırma ve değerlendirme yöntemleri. (Çeviri Ed. Mesut Bütün- Selçuk Beşir Demir). Ankara: Pegem.

Polat, S. (2007).Ortä̈gretim ögretmenlerinin örgütsel adalet algzlar, örgütsel güven düreyleri ile örgütsel vatandaşllk. davramışlar arasındaki ilişki (Yayımlanmış doktora tezi). Kocaeli Üniversitesi, Sosyal Bilimler Enstitüsü, Kocaeli.

Perks, H. \& Halliday, S.V. (2003).Sources, signs and signalling for fast trust creation in organisational relationships. European Management Journal.21(3), 338-350.

Sargut, A. S. (2001).Kültürlerarası fark hlasma ve yönetim. Ankara: İmge.

Seashore Louis, K. (2007). Trust and improvement in schools.Journal of Educational Change.8, 1-24.

Şişman, M. (2014).Türk eğitim sistemi ve okul yönetimi. Ankara: Pegem A.

Strier, M. \& Katz, H. (2016).Trust and parents' involvement in schools of choice.Educational Management Administration and Leadership.44(3), 363-379.

Şan, M. K. (2007), "Sosyal Bilimlerde Yıldızı Yükselen Yeni Bir Kavram: Sosyal Sermaye Ve Türkiye”, Sosyoloji Yazıları I, Sakarya Üniversitesi Sosyoloji Bölümü Ortak Çalışması, Der: M.K. Şan. s. 282-323, İstanbul: Kızılelma.

Tschannen-Moran, M. \& Hoy, W. K. (1998). Trust in schools: A conceptual and empirical analysis. Journal of Educational Administration. 36(4), 334-352.

Tschannen-Moran, M. \& W. Hoy (2000), A multidisciplinary analysis of the nature, meaning, and measurement of trust. Review of Educational Research. 70(4), 547-593.

Yıldırım, N. (2013). Okul Gelişimi. Servet Özdemir (Ed.), Eğitim Yönetiminde Kuram ve Uygulama içinde (s. 355-380). Ankara: Pegem A.

Yıldırım, A. ve Şimşek, H. (2008). Sosyal bilimlerde nitel araștırma yöntemleri. Ankara: Seçkin. 
Güçlü, N., Tepe, N., \&Duman, Ş. (2017). Öğretim kapasitesinin sosyal bir göstergesi olarak kolektif güven: Nitel bir araşturma. Journal of Human Sciences, 14(2), 1284-1297. doi:10.14687/jhs.v14i2.4492

\title{
Extended English Abstract
}

\begin{abstract}
Instructional capacity at school has two interconnected basic characteristics. These are: resources which enable increase of teaching efficiency at schools and social processes which would enable occupational learning through forming information (Curt, 2012). Collective trust which is in the social step of instructional capacity is the characteristics of a stable group which has rooted perceptions and effected by the reliability of another group or individual (Forsyth, Adams, and Hoy, 2011). It is based on openness, honesty, cooperativeness and competency (Hoy and Tschannen-Moran, 1999). Collective trust is a social process which increases instructional capacity at school. Schools with high learning capacity aim to learn together. Leadership for everyone, learning for everyone and increasing success for everyone are the basic aims. More permanent and joyful learning is enabled by forming cooperative learning environment at these schools. The principal is only one of the leaders at schools and serves as role model in listening, cooperation and harmony. All the individuals'share vision and knows what to do to reach the aim and how to contribute. Communication at school reflects the quality of school. Student makes contribution to the system with his success in the process (Lambert, 2005). The aim of this study in which learning capacity and collective trust terms are discussed is to determine the views of school principals about collective trust. Moreover, within this aim it was determined as sub-aims to analyze factors such as reliability, openness, honesty, helpfulness and competency in the process of school management.
\end{abstract}

\section{Method}

In this study used out within the scope of "phenomenology" pattern which is one of the qualitative research patterns. The study group is composed of 10 school principals who were chosen with simple random sampling method. 3 of the principals are female and 7 of them are male; all of them serve at state secondary schools. In the light of the study, semi-structured interview form which is composed of open-ended questions that is one of the qualitative data collection tools was used. Some questions were supported with drilling questions according to its content. Data collected were analyzed with content analysis. The study was encoded separately by both researchers in order to enable reliability of the study.

\section{Result}

In this study collective trust was analyzed in five dimensions namely helpfulness, reliability, competency, honesty and openness. With the analysis of research data it is possible to come up to these results in five dimensions. These findings and their implication for research and practice are discussed next:

In helpfulness dimension: Teachers are self-sacrificing in all circumstances and work devotedly both for students and for the school unconditionally. Most of the students exhibit helpful traits but behave helpfully according to their interests. Parents do not exhibit helpful behaviors too much. Great majority of them stay indifferent towards education or expect everything from state-teacherschool. However, only a few of them act helpfully for the education and for their children; and again a few more behave helpful much as they are necessarily and sufficiently informed about related issues. In reliability dimension; principals stated that the most reliable people are teachers, nearly all the parents and most of the students are also reliable. In honesty dimension; principals stated that the most reliable people are teachers, most of the parents are also reliable and reliability degree of students varies according to their interests from time to time. In competency dimension; most of the principals stated that they would prefer people who are competent at the job. The rest of them stated that they give importance to informal relations and sometimes they would prefer both methods according to situation. In openness dimension; school managers act according to the limits of laws, and share information with everybody as much as it requires. However, they also stated that they do not stay behind closed doors, always open to 
communication with teachers, students or parents; adopt open, clear and transparent sense of management. According to the results of study, it mayseem that at the schools of principals with whom the interview was done, the sense of collective trust was adopted. When a general evaluation is done, it can be said that a good leader is also a reliable leader, and a reliable leader would contribute to the increase of organizational commitment. It may seem that the quality of education increases at schools where collective trust is enabled and human relations develop in positive way.

\section{Suggestions}

In school management, environments should be formed where collective trust bonds are enabled among all stakeholders (manager-teacher-student-parent). In this environment, stakeholders should know each other very well and be aware of their requests and demands. People who trust in each other would break the walls between them and become open to communication. In this way, they would work fondly and devotedly in order to increase the quality of instructional activities. It should be frequently emphasized to students that honesty is one of the basic values and they should be encouraged to tell the truth all the time and under any circumstances. Various projects should be developed in order to improve sense of helpfulness of students, but they should be transformed into behaviour by emphasizing that they need to be done unconditionally. Parents should be encouraged and informed on necessary issues and their commitment to school should be increased. Various practical seminars and activities can be organized for this aim. It should be considered that there are differences between teacher, student and parents. Moreover, the most important method should be preferred in sharing information by considering the region of school and the structure of culture. Accuracy and competency should not be ignored in things to be done about education, works should absolutely be done by the expert. While forming the collective trust, the first step should be taken by the principal as the leader of school. The principal should indicate that he trusts in the people in order to enable the change and development of school and increase the quality of education. In this way, teacher, students or parents who understand that they are trusted would get one step closer to the school and fulfill their responsibilities willingly and fondly. 